\title{
Culex pipiens in London Underground tunnels: differentiation between surface and subterranean populations
}

\author{
KATHARINE BYRNE* \& RICHARD A. NICHOLS \\ Queen Mary and Westfield College, University of London, Mile End Road, London E1 4NS, U.K.
}

\begin{abstract}
Genetic variation was quantified between surface-dwelling populations of Culex pipiens and the so-called molestus form found in the London Underground (the Underground) railway system. The molestus form is a commercially important biting nuisance and in the southern part of its range is also a disease vector. The surface and subterranean populations were genetically distinct, with no evidence of gene flow between closely adjacent populations of the different forms, whereas there was little differentiation between the different populations of each form. The substantially reduced heterozygosity in the Underground populations and the allelic composition suggest that colonization of the Underground has occurred once or very few times. Breeding experiments show compatibility between the Underground populations but not with those breeding above ground. There is evidence of greater gene flow and a mixing of molestus and pipiens traits in the south of the species range. This paper considers the processes that may allow establishment of reproductive isolation in the north of the species range but not in the south.
\end{abstract}

Keywords: Culex pipiens, population structure, reproductive isolation.

\section{Introduction}

In London and other areas of northern Europe there are populations of Culex pipiens which have drawn particular attention, not least because they will bite humans voraciously and breed in confined underground spaces. This molestus form of C. pipiens became notorious during the 1939-45 war because it attacked Londoners seeking shelter from German bombing in the underground railway tunnels (Shute, 1951) and continues to be a sporadic biting pest to maintenance workers. It is one of a group of closely related species that forms the C. pipiens species complex. It is morphologically indistinguishable from the C.pipiens that is found in surface populations; yet these are bird biting, and show other substantial differences in behaviour and ecology (Table 1 and see Service, 1993).

These differences can be interpreted in a straightforward way as adaptations to a subterranean life: the ability to breed in confined spaces is a prerequisite; the greater warmth underground during winter

\footnotetext{
*Correspondence and present address: Conservation Genetics Group, Institute of Zoology, Regents Park, London NW1 4RY, U.K. E-mail: k.byrne@ucl.ac.uk
}

means that there is no need for a diapause; nutrients are more readily obtained in the larval stage or from mammals rather than from birds. These differences are heritable (Pasteur, 1977), and presumably maladaptive in the above-ground environment. Interbreeding with above-ground populations is additionally hampered by the physical separation of the two habitats.

The disruptive selection for the major adaptations to the above- and below-ground environments, and the isolation of the populations are the types of factor that are thought to help establish reproductive isolation (Rice \& Hostert, 1993; Bush, 1994), possibly via pleiotropy and/or genetic hitchhiking. Indeed, where the two mosquito forms have been found swarming together, genetic studies of the offspring have established that there is partial reproductive isolation, perhaps because of differences in mating flight (Urbanelli et al., 1981).

In the light of these differences it is not surprising that some authorities have regarded the subterranean form as a distinct species C. molestus (Miles, 1977a,b; Miles \& Patterson, 1979). On the other hand, many authors maintain that the pipiens and molestus forms are the same species, with any differ- 
Table 1 A comparison of the two forms of Culex pipiens

\begin{tabular}{|c|c|c|}
\hline Character & molestus & pipiens \\
\hline Breeding site & $\begin{array}{l}\text { Hypogeous } \\
\text { (underground) }\end{array}$ & $\begin{array}{l}\text { Epigeous } \\
\text { (above ground) }\end{array}$ \\
\hline Mating & $\begin{array}{l}\text { Stenogamous } \\
\text { (occurs in confined spaces) }\end{array}$ & $\begin{array}{l}\text { Eurygamous } \\
\text { (cannot occur in confined spaces) }\end{array}$ \\
\hline Host preference & $\begin{array}{l}\text { Mammophilic } \\
\text { (bites mammals) }\end{array}$ & $\begin{array}{l}\text { Ornithophilic } \\
\text { (bites birds) }\end{array}$ \\
\hline Life cycle & $\begin{array}{l}\text { Homodynamic } \\
\text { (no winter diapause) }\end{array}$ & $\begin{array}{l}\text { Heterodynamic } \\
\text { (winter diapause) }\end{array}$ \\
\hline
\end{tabular}

ences being purely physiological variation (e.g. Harbach et al., 1984). Between these two extremes are those who consider them as subspecies or semispecies (e.g. Urbanelli et al., 1981; Bullini, 1982). In this study no assumptions have been made about the taxonomic status of the two types of Culex. The terms pipiens and molestus form will be used to distinguish populations on the basis of the traits set out in Table 1.

In fact, the differentiation between pipiens and molestus forms seems to change from place to place within the range of the species. The ostensibly clearcut distinction between the molestus and pipiens forms in northern Europe is not so apparent in the northern Mediterranean area and may disappear in some populations further south-close to where its range meets that of its subtropical and tropical counterpart C. quinquefasciatus. In Spain (Chevillon et al., 1995) and the south of France (Pasteur et al., 1977) there are comparable differences between the populations breeding at the surface and enclosed sites ('epigeous' and 'hypogeous'), although Chevillon et al. (1995) did not find a categorical association between molestus/pipiens traits and hypogeous/ epigeous breeding sites. Furthermore, intermediate forms with a mixture of molestus and pipiens traits were detected, suggesting that hybridization between the two forms was occurring.

Directing our attention further south still, Villani et al. (1986) and Nudelman et al. (1988) claimed that in the Middle East (Israel and Egypt) the populations show no differentiation into pipiens and molestus, and that populations in all types of breeding sites contain females that can breed without a blood meal (i.e. they are autogenous). Similarly there is no clear association between habitat and host preference. Reports from Israel suggest that populations showed no significant differences between prefer- ence for birds or mammals (Nudelman et al., 1988), whereas in Egypt mammals were reported as being the favoured host (Zimmerman et al., 1985).

Another intriguing similarity between the southernmost populations and the molestus form has been found in genetic surveys. Mosquito populations from the Middle East are more similar to the European molestus form, displaying both low heterozygosity and high frequency of particular alleles (Villani et al., 1986).

This study made use of the populations in the tunnels of the London Underground (the Underground) railway and surrounding regions. The advantages of this system include its known interconnectedness and age, and a history of occupation by the molestus form. An above-ground collection was made in the vicinity of each one below ground. The aim was to assess the genetic differentiation within and between the two forms and to answer the following questions.

1 The subterranean and surface populations of C. pipiens in Britain are more distinct in terms of ecology and behaviour than equivalent populations in the south of the range. Is this associated with reduced gene flow and/or reproductive isolation between the molestus and pipiens forms?

2 Has there been one or several independent colonizations of the London Underground system, either through selection of molestus traits or by environmental changes triggering the expression of pre-existing characters?

3 Have molestus populations originated from longdistance migrants of surface-living molestus-type individuals from the south of the range? This idea arises from two sources. First, that $C$. pipiens in the Middle East are more similar to the European molestus form than pipiens (Villani et al., 1986), and, secondly, that long-distance migration on this

(c) The Genetical Society of Great Britain, Heredity, 82, 7-15. 
geographical scale appears to have been demonstrated by the spread of insecticide-resistance alleles (Raymond et al., 1991).

\section{Materials and methods}

\section{Collection sites}

Samples were collected from breeding sites at 20 locations in London. Full sample details are shown in Table 2. Subterranean populations (seven) were collected during expeditions accompanying London Underground maintenance crews. Immature stages (egg rafts, larvae and pupae) were collected from pools, flooded sumps and shafts. Surface populations (11) were collected from garden ponds and water butts on allotments and were chosen as close to each Underground site as was practicable so that direct comparison could be made between them. A population of human-biting, adult females was collected from the interior of houses in Beckton, south-east London, where they had been causing a severe biting nuisance. One population (Oval) was of inde- terminate status, being under open sky at the foot of a ventilation shaft. Additionally, a cultured autogenous population (Mogden) was included in the analysis. This population was originally collected by White (see Villani \& Hemingway, 1987) from Mogden Sewage Works in west London. Full details of sampling techniques are given in Byrne (1996).

\section{Mosquito rearing}

Preimaginal stages were reared in plastic containers in the laboratory at room temperature under conditions of natural light, in water collected from the breeding site. Guinea pig pellets were provided as a larval food source as required. Pupae were picked from the larval trays using a plastic pipette and transferred to small enamel dishes, which were placed in $20 \mathrm{~cm}$ nylon and wire frame cages. The adults were allowed to emerge in these cages which contained a $12 \mathrm{~cm}$ diameter Whatman filter paper soaked in $10 \%$ glucose as an energy source. Each cage was provided with a small $(4 \mathrm{~cm}$ diameter $)$

Table 2 Mosquito collection sites and population characteristics

\begin{tabular}{|c|c|c|}
\hline Population & Breeding site and type & Place of collection \\
\hline Euston & UA & $\begin{array}{l}\text { London Underground. Beneath track rails of Victoria Line, } \\
\text { northbound platform area }\end{array}$ \\
\hline Finsbury Park & UA & $\begin{array}{l}\text { London Underground. Beneath track rails of Victoria Line, } \\
\text { northbound platform area }\end{array}$ \\
\hline Shepherd's Bush & UA & London Underground. Invert beneath platform. Westbound platform \\
\hline Liverpool Street & UA & $\begin{array}{l}\text { London Underground. Drainage sumps beneath track, platform area } \\
\text { and tunnel. Eastbound track }\end{array}$ \\
\hline Elephant and Castle & UA & $\begin{array}{l}\text { London Underground. Water collection in tunnel. Northbound from } \\
\text { station. Bakerloo Line }\end{array}$ \\
\hline Waterloo & UA & $\begin{array}{l}\text { London Underground. Tunnel area. Southbound from station. } \\
\text { Bakerloo Line }\end{array}$ \\
\hline Mogden & UA & Sewage works. Isleworth. Middlesex \\
\hline Beckton & ON & Inside houses. Winsor Park Estate E6 \\
\hline Oval & UN & $\begin{array}{l}\text { London Underground. Flooded service tunnel running parallel to } \\
\text { southbound platform }\end{array}$ \\
\hline Vauxhall & ON & Garden bucket. Kenchester Close SW8 \\
\hline Kennington & ON & Garden pond. Lorrimore Square SE17 \\
\hline Goldhawk Road & ON & Garden bucket. Line Grove W12 \\
\hline BBC White City & ON & Blue Peter garden. BBC TV centre. Wood Lane W12 \\
\hline Queen's Park & ON & Garden water butt. Bravington Road W9 \\
\hline Tufnell Park (I) & ON & Garden bucket. Tufnell Park Road N7 \\
\hline Tufnell Park (II) & ON & Garden bucket. Tufnell Park Road N7 \\
\hline Walthamstow & ON & Allotment. Queen's Road E17 \\
\hline Leytonstone & ON & Garden water butt. Harrington Road E11 \\
\hline Hounslow & ON & Garden water butt. Fir tree Road. Middlesex \\
\hline Shadwell & ON & Allotment. Cable Street E1 \\
\hline
\end{tabular}

Breeding Site: $\mathrm{U}$, underground; $\mathrm{O}$, overground. Type: A, autogenous; $\mathrm{N}$, anautogenous. 
enamel dish for oviposition, containing tap water and a small guinea pig pellet. Populations were labelled molestus if the laboratory-reared adults produced egg rafts (i.e. they were both stenogamous and autogenous) and pipiens if they did not. Adults were frozen in liquid nitrogen within 2 weeks of emergence and stored at $-70^{\circ} \mathrm{C}$ for later analysis.

\section{Crossing experiments}

Once breeding colonies of some populations had been successfully established, attempts were made to cross them. Virgin females of the autogenous Underground populations (Euston, Shepherd's Bush, Elephant and Castle and Mogden) were isolated by placing individual pupae in $50 \mathrm{~mL}$ Falcon tubes covered with netting. Reciprocal crosses were carried out between these populations by placing the females in a cage with five males taken from one of the other populations. A control cross with a male and female from the same population was also carried out. Unidirectional crosses using females from the same populations were carried out using males from some of the surface populations (Walthamstow, Leyton and the two Tufnell Park populations). The results of the crosses were scored as positive if viable egg rafts were produced or negative if they were not. Where $F_{1}$ generations were produced these were raised separately and scored for the production of an $\mathrm{F}_{2}$ generation.

\section{Laboratory methods}

The electrophoretic polymorphism of 20 allozyme loci was studied by cellulose acetate gel electrophoresis as described in Byrne (1996) and full details are available at http://www.qmw.ac.uk/ ugbt112. Individuals from the Shepherd's Bush population were used to standardize allele mobilities and samples from this population were run on every gel.

\section{Analysis of data}

Indices of genetic differentiation Allele frequencies at each locus were calculated for each population and used to calculate Nei's genetic distance $(D)$ and $G_{\text {ST }}$ (see Nei, 1987). Principal co-ordinate analysis on a matrix of pairwise $G_{\mathrm{ST}}$ values was carried out using the PCO command of Genstat (Genstat 5 Committee, 1987, p. 481). A summary of allele frequencies is available with the electrophoresis conditions on the website given above. Genetic distances and $G_{\mathrm{ST}}$ values are given in Table 3.

Mantel tests The statistical significance of the effects of geographical distance, division into subterranean and surface populations and division by Underground line on genetic distance were tested by a series of Mantel tests. The tests were performed using the R Package (Legendre \& Vaudor, 1991) and are shown in Table 4.

\section{Results}

\section{Population types}

The populations collected from the London Underground all produced egg rafts under laboratory conditions, with the exception of that found at the Oval. As the adults had been reared from larval stages, mating and oviposition all occurred within the cages. The Oval population failed to produce egg rafts and was labelled pipiens type, along with the surface populations. The Mogden population was also molestus. The Beckton population could not be assigned any status as no $F_{1}$ was produced from the adult females collected. The other characters typical of the molestus type could not be scored as easily. Homodynamy, the ability to breed continuously without a winter diapause, did occur in laboratory conditions, even under the natural light regime employed, and the presence of mosquito populations

Table 3 Range of $D$ and $G_{\mathrm{ST}}$ values between different mosquito populations. Figures in parentheses are means

\begin{tabular}{|c|c|c|c|c|c|c|c|c|}
\hline & $\begin{array}{l}\text { Between } \\
\text { underground } \\
\text { populations }\end{array}$ & $\begin{array}{l}\text { Between } \\
\text { surface } \\
\text { populations }\end{array}$ & $\begin{array}{l}\text { Between } \\
\text { underground } \\
\text { and surface } \\
\text { populations }\end{array}$ & $\begin{array}{l}\text { Between } \\
\text { underground } \\
\text { and Mogden } \\
\text { populations }\end{array}$ & $\begin{array}{l}\text { Between } \\
\text { surface } \\
\text { and Mogden } \\
\text { populations }\end{array}$ & $\begin{array}{l}\text { Between } \\
\text { underground } \\
\text { and Beckton } \\
\text { populations }\end{array}$ & $\begin{array}{l}\text { Between } \\
\text { surface } \\
\text { and Beckton } \\
\text { populations }\end{array}$ & $\begin{array}{l}\text { Between } \\
\text { Mogden } \\
\text { and Beckton } \\
\text { populations }\end{array}$ \\
\hline$D$ & $\begin{array}{c}0.0001-0.04 \\
(0.025)\end{array}$ & $\begin{array}{c}0.017-0.1000 \\
(0.05)\end{array}$ & $\begin{array}{c}0.07-0.23 \\
(0.20)\end{array}$ & $\begin{array}{c}0.025-0.26 \\
(0.23)\end{array}$ & $\begin{array}{c}0.13-0.27 \\
\quad(0.20)\end{array}$ & $\begin{array}{c}0.006-0.05 \\
(0.03)\end{array}$ & $\begin{array}{c}0.055-0.16 \\
(0.12)\end{array}$ & 0.18 \\
\hline$G_{\mathrm{ST}}$ & $\begin{array}{c}0.001-0.20 \\
(0.15)\end{array}$ & $\begin{array}{c}0.02-0.13 \\
\quad(0.06)\end{array}$ & $\begin{array}{c}0.15-0.38 \\
\quad(0.28)\end{array}$ & $\begin{array}{c}0.54-0.72 \\
\quad(0.62)\end{array}$ & $\begin{array}{c}0.27-0.44 \\
\quad(0.34)\end{array}$ & $\begin{array}{c}0.050-0.21 \\
(0.12)\end{array}$ & $\begin{array}{c}0.11-0.25 \\
\quad(0.19)\end{array}$ & 0.48 \\
\hline
\end{tabular}


Table 4 Mantel tests for mosquito populations. The test statistic $t$ is the standardized Mantel statistic. Probabilities refer to estimates of the probability of obtaining the results by chance under the null hypothesis of no relationship

\begin{tabular}{llllc}
\hline Test number & \multicolumn{1}{c}{ Variables compared } & \multicolumn{1}{c}{ Populations } & \multirow{2}{*}{ Probability $(P)$} \\
\hline 1 & Genetic distance vs. geographical distance & All & 1.384 & 0.083 \\
2 & Genetic distance vs. geographical distance & Surface & 0.621 & 0.267 \\
3 & Genetic distance vs. geographical distance & London Underground & 0.097 & 0.461 \\
4 & Genetic distance vs. categories above ground/below ground & All & 10.457 & $<0.00001$ \\
5 & Genetic distance vs. category Underground line & London Underground & 2.138 & 0.016 \\
6 & Beckton is no different from the Underground & molestus & 0.692 & 0.244 \\
7 & Mogden is no different from the Underground & molestus & 2.627 & 0.004 \\
\hline
\end{tabular}

in the Underground system throughout the winter months suggested that this character was present in at least some individuals. Host preference was not tested directly. Only the Beckton population, in which adults were collected after having bitten humans, was known to be using a mammal host, although it is not known whether they would also have used birds.

\section{Crosses}

All crosses between molestus populations resulted in a viable $F_{1}$ generation. All of these $F_{1}$ generations went on to produce a viable $F_{2}$ generation. Conversely, none of the crosses between surface males and autogenous females resulted in any offspring, demonstrating a lack of stenogamy in surface-population males The females used in these crosses were allowed 1 week to produce egg rafts and were then isolated from the males for a further week. After this time they were placed with males from their own population. All but two females went on to produce egg rafts following exposure to males from their own population. The allele frequencies of the offspring showed that the molestus males had fathered the offspring. One intermediate result was obtained. When Oval males were crossed with one female from the Euston population a viable egg raft was produced; however, the $F_{1}$ population failed to produce an $\mathrm{F}_{2}$ generation.

\section{Allele frequencies}

For each locus 20 individuals were scored and the allele frequencies calculated. Of the 20 loci scored, all but two (Me-1 and $G p d)$ were polymorphic in some of the populations. Surface populations were considerably more polymorphic than those collected from the Underground. Only two loci ( $\mathrm{Hk}$ and $\mathrm{Mpi}$ ) were polymorphic in all of the Underground populations. Preliminary inspection of the allele frequency data shows some of the fundamental differences between the pipiens and molestus populations. The molestus populations do not have any unique alleles but a subset of those found in the surface $C$. pipiens populations. There is a striking difference between the two types in levels of polymorphism. The molestus populations show a consistent reduction in polymorphism to about a quarter of the heterozygosity when compared to the surface-dwelling populations (mean $H_{\text {surface }}=0.27, H_{\text {Underground }}=0.07$ ) The Mogden population has an even lower heterozygosity than those from the Underground $\left(H_{\text {Mogden }}=0.05\right)$, which is consistent with the fact that they have been in long-term culture.

\section{Principal co-ordinate analysis}

An immediate picture of variation among the populations can be gained from Fig. 1, which shows the principal co-ordinate analysis of $G_{\mathrm{ST}}$. There are three clusters: (i) the populations from the London Underground (घ) and Beckton ( $\square$ ); (ii) the surface C. pipiens (ム) and Oval Underground $(\triangle)$; and (iii) the Mogden molestus population (○).

\section{Mantel tests}

The results of the Mantel tests are shown in Table 4. There is no clear association between geographical and genetic distances in the total population (test 1, $P=0.08$ ), the surface populations (test $2, P=0.27$ ) or the London Underground populations (test 3, $P=0.46$ ). The Mogden population is responsible for the borderline significance in the total population, as not only is it genetically distinct but it is also geographically the most distant. In contrast the Underground populations were clearly distinct from the surface populations (test $4, P<0.001$ ). The Beckton population is not distinguishable from the London Underground populations (test $6, P=0.25$ ), whereas Mogden, a laboratory population, could be 


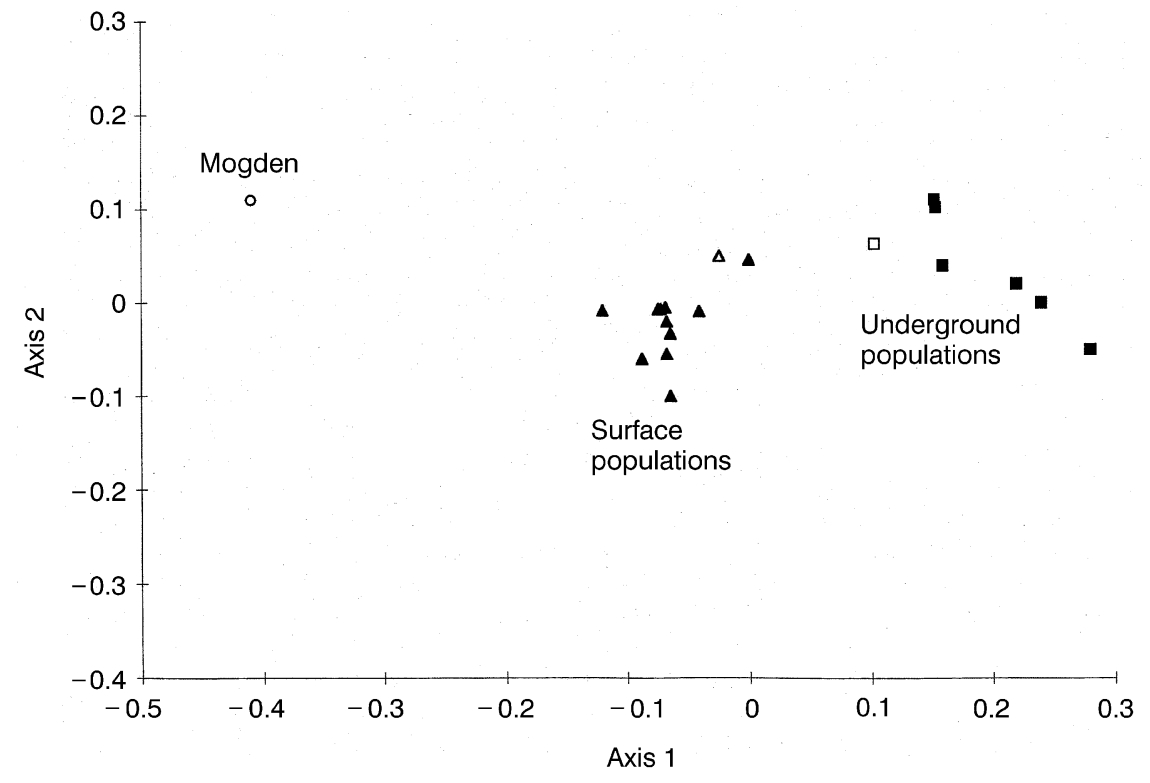

Fig. 1 Principal co-ordinate analysis of $G_{\mathrm{ST}}$ showing the first two principal co-ordinates used to analyse the difference in $G_{\mathrm{ST}}$ between 20 populations of Culex pipiens collected from above and below ground in London. It demonstrates that the populations cluster into two major groups, which correspond to: (i) molestus populations from the London Underground (घ) and Beckton ( $\square$ ); and (ii) the surface Culex pipiens populations ( $\mathbf{(})$ and the Oval population $(\triangle)$. Mogden $(\bigcirc)$ is an outlier. distinguished (test $7, P<0.005$ ). There was significant differentiation between the three Underground lines, (test 5, $P=0.016$ ).

\section{Discussion}

\section{Levels of genetic differentiation}

The initial assignment of two population types based on laboratory mating behaviour suggested that there were two distinct groups, which correlated to hypogeous (enclosed) and epigeous (open) breeding sites. The genetic data also show significant support for the division of the London population of C. pipiens into two subgroups, pipiens and molestus, which correspond to the different breeding behaviour in the laboratory. This result is readily apparent from the ordination of $G_{\mathrm{ST}}$ values, which clusters the populations into two groups. The separation into two distinct clusters indicates that gene flow between the two is absent or limited. Each subterranean population was paired with a surface population close by, so appreciable gene flow over a few hundred metres would have been sufficient to produce a thorough intermingling of the two categories of population in the ordination.

Two observations suggest that even where molestus and pipiens populations are in contact gene flow is limited or, conceivably, absent. First, the Oval population ( $\triangle$, Fig. 1), clusters with the surface populations on the criteria of genetic distance and postmating and premating reproductive isolation, despite being underground (although open to the sky). Similarly, a previous study by Chevillon et al. (1995) found that mosquitoes collected from what they termed 'open hypogeous sites' were not differentiated from epigeous populations. Secondly, the Beckton population ( $\square$, Fig. 1) is clearly flying on the surface to reach its human victims. Although the breeding sites beneath houses have been blocked, other sites have not yet been located by the pest control authorities; one possibility is the large containers on an adjacent but inaccessible derelict industrial site. The genetic data only give a hint of gene flow: Beckton clearly clusters with the Underground populations, but it does show higher heterozygosity than the Underground populations, which might be a consequence of limited gene exchange with the local surface populations.

The Underground populations are much less tightly clustered than those overground, suggesting that gene flow is more limited or genetic drift relatively stronger. The significant genetic differentiation between lines (see Table 4) can be explained as a consequence of the shaping of gene flow by the tunnel system. Whereas the lines run through tunnels connected principally at the interchange stations, the piston-like action of trains within a tunnel creates a strong draught that may move the adults between breeding sites on the same line.

This picture of isolation contrasts with genetic studies from more southerly populations (France, Spain and Italy), where there is more evidence of extensive gene flow between pipiens and molestus 
populations. The penetration of insecticide-resistance genes into hypogeous populations (Rivet \& Pasteur, 1993; Chevillon et al., 1995) provides the most straightforward case. This transmission of resistance alleles is not necessarily an indication of frequent gene exchange, as the strong selection pressure imposed by insecticide use could have established resistance in the hypogeous populations from a very small number of successful migrants. More straightforward evidence comes from Italy (Urbanelli et al., 1981). Three types of population were found on the basis of genetic surveys of allozyme loci: those consisting solely of C.pipiens pipiens, others consisting solely of $C . p$. molestus and also populations which were intermediate and were presumed to have arisen by hybridization of the other populations.

\section{Reproductive isolation}

The lack of demonstrable gene flow between the two forms in London may, in part, be explained by the implications of the breeding experiments, in which no offspring were recorded from crosses between Underground and surface populations. The ability to mate in confined spaces (stenogamy) may be a major contribution to premating reproductive isolation. Intriguingly, the Oval population, which seems to be an essentially overground population living underground (but below open sky) produced one $\left(F_{1}\right)$ egg raft. The $F_{2}$ eggs, however, failed to hatch.

The genetic distances measured by the present study between the Underground and surface populations (0.07-0.24) would suggest that the relationship between the two population types is between that of local populations and subspecies (see Ayala, 1975). However, genetic distances may not be useful in populations where demographic effects are the dominant factor in the population history; for example, they do not reliably separate domestic livestock breeds (see, e.g. MacHugh et al., 1997). Using Nei's formula (see Nei, 1987), the estimated time since separation of the surface and Underground populations is $\approx 100000$ years, even using the correction for drift in one population. This timescale is, of course, inconsistent with the known history of the tunnels, most of which are less than 100 years old. A second illustration of the imprecise nature of such estimates of separation time is provided by the Mogden population, which has only existed as a caged population for $\approx 10$ years and yet is as distinct as molestus and pipiens. These differences can be explained as a combination of severe genetic drift and the effects of selection in a caged environment. This laboratory history may be analogous to that of populations that adapt to a subterranean life in the wild: they may also be presumed to have experienced strong selection and substantial genetic drift.

\section{Origin of the Underground populations}

Two possible sources were considered for the colonization of the London Underground-local London surface populations and long-distance migrants from Mediterranean populations.

Long-distance migrants Populations of C.pipiens from the Mediterranean region, especially those from North Africa, show similarities to molestus populations from Britain. In particular, they have reduced polymorphism and higher frequency of some alleles associated with the Underground populations (Villani et al., 1986). Little evidence has been found to support the proposal that the London Underground was colonized from this source. The alleles found in the Underground do not include any that are otherwise found only outside Britain. Only Got-1 is fixed for an allele that is rare on the surface but that is frequent in molestus-type individuals from other areas (Chevillon et al., 1998). The identity of alleles was confirmed by cross-checking with control strains provided by M. Raymond.

Local colonization The data are more consistent with local populations being the source of molestus populations in the Underground. However, Fig. 1 shows that there is no association between individual Underground populations and local surface populations, which suggests that multiple independent colonizations are unlikely or, at least, that such events are rare. The most parsimonious explanation is a single colonization. This would explain the fixation of a single allele at multiple allele loci such as the esterases. The similarity of the Underground populations to the more distant Beckton population (nearest Underground line $4 \mathrm{~km}$ ) raises the possibility that adaptation to the underground environment may have occurred only once, and that the established subterranean populations are the source for subsequent colonizations.

\section{Adaptation, population fragmentation and reproductive isolation}

The distinction between pipiens and molestus forms appears to increase with latitude. This pattern can 
be interpreted in terms of the interplay of deterministic and stochastic processes that can lead to reproductive isolation. The requirement for a winter diapause at high latitudes may play a pivotal role. In North Africa (below $38^{\circ} \mathrm{N}$ ) the above-ground populations are diapause-incompetent, a pattern that may be related to day length (Zimmerman et al., 1985). At the other extreme of the range, northern European subterranean populations become isolated from the surface populations with the onset of diapause in the surface form in the Autumn. Gene flow is therefore restricted for two reasons. First, there is a shorter period when breeding in the two forms overlaps. Secondly, if subterranean populations set up satellite populations above ground, they will not survive the winter and will only have a limited life during which they could act as steppingstones for gene exchange.

These trends vary in a predictable way from the south to the north of the range. The intervening northern Mediterranean populations show the expected evidence of intermediate gene flow and this would explain the diminished differentiation into molestus and pipiens forms. Two stochastic processes also come into play in the north of the range. Genetic drift will tend to fix molestus traits in subterranean populations. The consequent linkage disequilibrium with eurygamy above ground and lack of diapause below ground will further hamper gene flow throughout the genome. In addition, the establishment of different clones of the Rickettsia-like bacterium Wolbachia pipientis can provide the coup de grâce to gene flow by leading to incompatibility of matings between differently infected populations. The crossing types are sufficiently labile to change from place to place and through time in the same population (Raymond et al., 1986; Magnin et al., 1987). Indeed C.pipiens shows a high number of incompatible cytotypes relative to other insects, despite the unexceptional degree of genetic divergence between their strains of Wolbachia, which may indicate interactions between Wolbachia and Culex genomes (Guillemaud et al., 1997).

This combination of factors can explain why gene flow is negligible or absent between the two forms in the populations that were studied. As it appears plausible that colonization of the London Underground has occurred only once, the reproductive isolation could have accumulated in the few hundred generations since then. Conversely, in the south of the range, where climate promotes more frequent gene flow, this may be sufficient to prevent the establishment of reproductive isolation, even though the pleiotropic effects of selection in the underground environment are the same.

\section{Acknow ledgements}

We would like to thank Michel Raymond and Nicole Pasteur for their assistance throughout the project and M. Ritchie and other reviewers for helpful comments on earlier drafts of the manuscript. K.B. was supported by a BBSRC studentship.

\section{References}

AYALA, F. J. 1975. Genetic differentiation during the speciation process. Evol. Biol., 8, 1-78.

BULLINI, L. 1982. The electrophoretic approach to the study of parasites and vectors. Parassitologia, 27, 1-11.

BUSH, G. L. 1994. Sympatric speciation in animals: new wine in old bottles. Trends Ecol. Evol., 9, 285-288.

BYRNE, к. 1996. Gene Flow and Insecticide Resistance in the Mosquito Culex pipiens. Ph.D. Thesis, University of London.

CHEVILLON, C., ERITJA, R., PASTEUR, N. AND RAYMOND, M. 1995. Commensalism, adaptation and gene flow: mosquitoes from the Culex pipiens complex in different habitats. Genet. Res., 66, 147-157.

CHEVILlON, C., RIVET, Y., RAYMOND, M., ROUSSET, F., SMOUSE, P. E. AND PASTEUR, N. 1998. Migration/selection balance and ecotypic differentiation in the mosquito Culex pipiens. Mol. Ecol., 7, in press.

GENSTAT 5 COMMITTEE, ROTHAMSTEAD EXPERIMENTAL Station. 1987. Genstat 5 Reference Manual. Oxford Science Publications, Clarendon Press, Oxford.

GUILlemaud, P., PASTEUR, N. AND ROUSSET, F. 1997. Contrasting levels of variability between cytoplasmic genomes and incompatibility types in the mosquito Culex pipiens. Proc. R. Soc. B, 264, 245-251.

HARBACH, R. E., HARRISON, B. A. AND GAD, A. M. 1984. Culex (Culex) molestus Forskål (Diptera: Culicidae): Neotype designation, description, variation and taxonomic status. Proc. Ent. Soc. Wash., 86, 521-542.

LEGENDRE, P. AND VAUDOR, A. 1991. The $R$ Package. University of Montreal. Web page-http://alize.Ere. umontreal.ca/ casgrain/R-v3/.

MACHUGH, D. E., SHRIVER, M. D., LOFTUS, R. T., CUNNINGHAM, P. AND BRADLEY, D. G. 1997. Microsatellite DNA variation and the evolution, domestication and phylogeography of taurine and zebu cattle (Bos taurus and Bos indicus). Genetics, 146, 1071-1086.

MAGNIN, M., PASTEUR, N. AND RAYMOND, M. 1987. Multiple incompatibilities within populations of Culex pipiens $\mathrm{L}$. in southern France. Genetica, 74, 125-130.

MILES, S. J. 1977a. Laboratory evidence for mate recognition behaviour in a member of the Culex pipiens complex (Diptera: Culicidae). Aust. J. Zool., 25, 491-498.

MILES, s. J. 1977b. Assortative mating between Culex fatigans and C. molestus (Diptera: Culicidae) under simu-

(C) The Genetical Society of Great Britain, Heredity, 82, 7-15. 
lated field conditions. J. Aust. Entomol. Soc., 16, 389-392.

MILES, S. J. AND PATTERSON, H. E. 1979. Protein variation and systematics in the Culex pipiens group of species. Mosquito Syst., 11, 187-202.

NEI, M. 1987. Molecular Evolutionary Genetics. Columbia University Press, New York.

NUDELMAN, S., GALUN, R., KITRON, U. AND SPIELMAN, A. 1988. Physiological characteristics of Culex pipiens in the Middle East. Med. Vet. Entomol., 2, 161-169.

PASTEur, N. 1977. Recherches de génétique chez Culex pipiens pipiens L. Polymorphisme enzymatique, autogénèse et résistance aux insecticides organophosphates. Thèse de Doctorat d'Etat, Université de Montpellier II.

PASTEUR, N., RIOUX, J. A., GUILVARD, E. AND PECH-PERIERES, J. 1977. Nouvelle mention pour le 'Midi' méditerranéen, de populations naturelles anautogènes et sténogames de Culex pipiens L. Annales Parasitologie, 52, 205-210.

RAYMOND, M., MAGNIN, M., PASTEUR, N., PASTEUR, G. AND SINÈGRE, G. 1986. Cytoplasmic incompatibility in the mosquito Culex pipiens L. from southern France: implications for the selection and dispersal of insecticide resistance genes in natural populations. Genetica, 70, 113-118.

RAYMOND, M., CALlAGHAN, A., FORT, P. AND PASTEUR, N. 1991. Worldwide migration of amplified insecticide resistance genes in mosquitoes. Nature, 350, 151-153.

RICE, W. R. AND HOSTERT, E. E. 1993. Laboratory experiments on speciation: what have we learned in 40 years? Evolution, 47, 1637-1653.

RIVET, Y. AND PASTEUR, N. 1993. Evolution of resistance genes in absence of insecticide selection in a hypogeous population of Culex pipiens from the French Alps. J. Am. Mosq. Contr. Ass., 9, 206-209.

RIVET, Y., MARQUiNe, M. AND RAYMOND, M. 1993. French mosquito populations invaded by A2-B2 esterases causing insecticide resistance. Biol. J. Linn. Soc., 49, $249-255$.

SERvice, M. 1993. Mosquitoes (Culicidae). In: Lane, R. P. and Crosskey, R. W. (eds) Medical Insects and Arachnids, pp. 120-140. Chapman and Hall, London.

Shute, P. G. 1951. Culex molestus. Trans. R. Ent. Soc. Lond., 102, 380-382.

SIRIVANAKARN, S. AND White, G. B. 1978. Neotype designation of Culex quinquefasciatus Say (Diptera: Culicidae). Proc. Entomol. Soc. Wash., 80, 360-372.

URBANELli, S., CIANCHI, R., PETRARCA, V., SABATINELli, M., COLUZZI, M. AND BULLINI, L. 1981. Adattamento all'ambiente urbano nella zanzara Culex pipiens (Diptera, Culicidae). In: Moroni, A., Ravera, O. and Anelli, A. (eds) Ecologia, Atti I Congressi nazionali S. It. E., pp. 305-316. Zara, Parma.

VILlAni, F. AND Hemingway, J. 1987. The detection and interaction of multiple organophosphorus and carbamate insecticide resistance genes in field populations of Culex pipiens from Italy. Pestic. Biochem. Physiol., 27, 218-228.

VILlANi, F., URBANELli, S., GAD, A., NUDELMAN, S. AND BULLINI, L. 1986. Electrophoretic variation of Culex pipiens from Egypt and Israel. Biol. J. Linn. Soc., 29, 49-62.

ZIMMERMAN, J. H., HANAFI, A. AND ABASSY, M. M. 1985. Host-feeding patterns of Culex mosquitoes (Diptera: Culicidae) on farms in Gharbiya Governate, Egypt. $J$. Med. Entomol., 22, 82-87. 